Cordero S., R.A., Garrido, A., Pérez-Molina, J.P., Ramírez-Alán, O., \& Chávez, J.L. (2021). Lichen community structure and richness in three mid-elevation secondary forests in Costa Rica. Revista de Biología Tropical, 69(2), 688-699. https://doi.org/10.15517/rbt.v69i2.46162

\title{
Lichen community structure and richness in three mid-elevation secondary forests in Costa Rica
}

\author{
Roberto A. Cordero S. ${ }^{1 *}$; (D) https://orcid.org/0000-0001-7270-104X \\ Ana Garrido²; (D) https://orcid.org/0000-0001-5343-5639 \\ Junior Pastor Pérez-Molina ${ }^{1}$; (D) https://orcid.org/0000-0002-3396-0599 \\ Óscar Ramírez-Alán ${ }^{\dagger}, 3$ \\ José Luis Chávez"; (D) https://orcid.org/0000-0002-3441-6202
}

1. Laboratorio de Ecología Funcional y Ecosistemas Tropicales, Escuela de Ciencias Biológicas, Universidad Nacional de Costa Rica, Heredia, Costa Rica; ticolamb@gmail.com, junior.perez.molina@una.ac.cr (Correspondence*)

2. Escuela de Ciencias Ambientales, Universidad Alcalá de Henares, Madrid, España; anagarridoquesada@hotmail.com

3. Escuela de Ciencias Biológicas, Universidad Nacional de Costa Rica, Heredia, Costa Rica.

4. Trabajador independiente. Tilarán, Costa Rica; jlchaves25@gmail.com

Received 10-III-2021. Corrected 19-V-2021. Accepted 02-VI-2021.

\begin{abstract}
Introduction: Lichen diversity, community structure, composition and species abundance have been used as indicators of the integrity and ecological continuity of tropical forest ecosystems. Objectives: To assess corticolous lichen species composition, diversity, and ecological importance of three forested stands differing in time of abandonment as indicators of how passive restoration influences the lichen community assemblage. Methods: We surveyed individual lichens on tree stems of a reference old secondary forest and a young secondary forest (50 and 14-year-old natural regeneration after pasture abandonment, respectively), and in a 35-year-old exotic cypress tree plantation, in the oriental Central Valley, in Orosí, Costa Rica. Standard diversity, similarity indexes, and the importance value index were calculated. An NMDS analysis was performed on the community structure parameters and in a presence-absence matrix. Results: We found 64 lichen species in 25 families with 42, 21, and 23 species, and 20,10, and 15 families, in the young and old secondary forests, and the cypress plantation, respectively. Cryptothecia sp. possessed the highest importance across sites. More than $87 \%$ of the species are rare. The combined IVI of the top three families were: $36,48.5$, and $74.8 \%$ in the young and old forests and the Cypress plantation sites, respectively. Overall, Arthoniaceae is in the top three families. The young forest had the highest species richness, but the old forest presented the best evenness. Similarity and diversity indexes suggest a particularly low resemblance in the lichen communities but a smooth gradient differentiation between the three forests, which was confirmed by the NMDS test. The homogeneity test identified great differences in ecological importance and composition. Conclusions: This region contains a distinctive assemblage of species resulting in a strong community differentiation by site, reflecting the influence of ecophysiological and microclimatic factors that define lichen establishment and survival and suggesting a great regional beta diversity, within a fragmented landscape. Greater connectivity and passive restoration strategies resulted in greater diversity and a more heterogeneous community structure on both forests than the corticolous community of the abandoned plantation. Protection of forest fragments will maximize the integrity of future forests.
\end{abstract}

Key words: cloud forest; community composition; corticolous lichens; Costa Rica; hemeroby; lichen diversity. 
Lichens have an important role at both the ecological and economical levels. Among their functions, they contribute to forest total biomass and provide food and shelter to other organisms (Galloway, 1992; Lehmkuhl, 2004). Many lichens can fix atmospheric nitrogen (Honegger, 1991), and they are common primary colonizers in almost every known ecosystem. Taken together, all these lichen traits can guide us to think of a relationship between increases in lichen diversity and biomass with the increasing structural complexity of forests (Crites \& Dale, 1998; Berryman \& McCune, 2006). More and more studies have focused on the lichen ecology in tropical ecosystems as model organisms for the study of diversity patterns (Lücking, 1999a). Recently, RivasPlata et al. (2008) have demonstrated how lichens can be used as ecological indicators of hemeroby across a series of life zones ranging from lowland rain forests to montane forests and from open to shaded microenvironments. Given their epiphytic position, lichens are indicators of habitat loss and ecosystem degradation because they rely on the permanence of their arboreal available substrates (Estrabou et al., 2005). A recent paleotropical study showed how lichen functional traits and taxonomy were useful to detect forest condition (Thüs et al., 2021).

For the same token, given their extreme ability to tolerate some extreme environmental conditions and their sensitivity to subtle changes in their microenvironmental situations, lichens have been traditionally used for biomonitoring atmospheric pollution around the world based solely on growth or dominance reduction (Monge-Nájera et al., 2002; Bustamante et al., 2011). More detailed studies use them coupled to bioindication techniques based on lichen species reduction and its direct relationship with some atmospheric pollutants (Giordani, 2007; Cristofolini et al., 2008). In addition, lichen studies have been related to ecosystem changes due to recent climate change and temperature increases. For example, a reduction of lichen dominance has been associated with increasingly milder conditions in some artic habitats due to increasing representation of vascular plant biomass (Cornelissen et al., 2001), and are considered excellent ecosystem indicators in several ways (Petrokas \& Baliuckas, 2017). Traditionally, lichen studies in more pristine areas have been mostly related to site-specific environmental gradients, such as the temperature, moisture, and latitudinal gradients (McCune, 2000), and, more recently, to include other microsites besides tree trunks (Gasparyan et al., 2018). Large scale studies in a paleotropical forest found that some tree species, bark traits, and tree size are key factors determining lichen community structure (Thüs et al., 2021).

In this study, we use lichens to compare how passive restoration after the abandonment of two pasture areas and a cypress plantation influenced the development of the lichen community and diversity. Recent evidence points out that the epiphytic lichen richness requires a mean of 180 years to reach old-growth forest richness (Spake et al., 2015). A simple way to compare communities based on species presence data and its dominance can be executed through the calculation of several well-known parameters and indexes, which are extensively used and discussed in the ecological literature such as Heltshe and Forrester (1983), Krebs (1999), Hubbell (2001), Condit et al. (2005), and López and Duque (2010).

This study aims to evaluate the corticolous lichen's diversity in terms of species richness and diversity as indicators of ecosystem condition in three forest covers differing in previous land use and time of abandonment. It emphasizes the significant role played in the time after abandonment and passive restoration in the diversity and distribution of lichens within a mid-elevation cloud forest in a tropical landscape.

\section{MATERIALS AND METHODS}

Study sites: This study comprises three different forested areas differing in the modes and degrees of restoration located around the Orosí Valley, on the oriental side of the Costa 
Rican Central Valley. The first two sites are located near the Río Macho Biological Station at El Llano (9 $\left.46^{\prime} \mathrm{N} \& 83^{\circ} 51^{\prime} \mathrm{W}\right)$, and a third one is close to Orosí town (Table 1). The first site is considered as the reference old secondary forest (OF) located in the lower montane rainy forest located at 1700 m.a.s.l. (Ortiz-Malavassi, 2014), with more than 50 yo of regeneration from abandoned pastures. We have observed more than 50 species of trees which include: Myrsine coriacea, Billia hippocastanum, Marila laxiflora, Miconia dodecandra, Cornus disciflora, Vismia baccifera, Clusia sp., Symphonia globulifera, Quercus sp., Saurauia montana, Saurauia yasicae, and several Ocotea species. In the same life ecological zone, the second site is a young secondary forest (YF), and it is located less than $1 \mathrm{~km}$ away from the forested site (at 1680 m.a.s.l.). This YF contains a natural regeneration forest of approximately 13 yo from pastures and an abandoned Syzygium jambos (Myrtaceae) plantation, and it is surrounded by other farms, old pastures in different states of abandonment, and the Western section limits with the natural forest. At least 16 tree species had been recorded, including $M$. coriacea, M. dodecandra, V. baccifera, Clusia sp., S. montana, S. yasicae, Topobea maurofernandeziana, Rubus roseifolius and $S$. jambos. The third site is a small, private, and unmanaged cypress plantation (CP) (Cupressus lusitanica) at least 35 yo originally planted on a previous coffee plantation, presently surrounded by sunny and shade-grown coffee and small riparian relicts of original forest (Table 1). This site is in the humid premontane forest life zone (Ortiz-Malavassi, 2014) at approximately 1 300 m.a.s.l. and $1 \mathrm{~km}$ North of Orosí town. In addition to the complete canopy dominance by the cypress tree crowns, at least 36 other tree species are starting to reach the lower canopy level. The most common tree species are several: Miconia spp., Viburnum spp., Zanthoxylum spp., Coffea arabica, Conostegia spp., and S. jambos.

Sampling methods: Despite the great diversity of available phorophytes for lichen establishment, we consider only corticolous (epixylic) lichens, those who establish only on standing tree barks. We consider the following aspects that may determine lichen establishment on tree trunks to sample, and measure: twenty subplots of $10 \times 10 \mathrm{~m}$ were randomly selected from 50 in each forest plot of 0.5 ha (Table 1). Within each subplot, the first two trees found with a diameter at breast height $>$ $10 \mathrm{~cm}$ were chosen to sample lichens. Bended trees ( $>10^{\circ}$ inclination) and extremely smooth or rough bark textures were avoided to homogenize possible species preferences for bark surfaces. Phorophyte species were not registered but, for the cypress plantation, all chosen trees were $C$. lusitanica (Cupressaceae).

Lichen sampling: A transparent plastic template $20 \times 10 \mathrm{~cm}$ was located against the tree bark at $1.5 \mathrm{~m}$ from the tree base to make

TABLE 1. Characteristics of the three study plots

\begin{tabular}{lccc}
\hline \multicolumn{1}{c}{ Locality } & Reserva Forestal Río Macho & Reserva Forestal Río Macho & Finca La Laja Orosí \\
\hline \multicolumn{1}{c}{ Plot name } & OF plot at El Llano & YF plot & CP plot \\
\hline Origin/age & Old secondary 50 yo & $\begin{array}{c}\text { Abandoned farm } \\
\text { and plantation } 13 \text { yo }\end{array}$ & Coffee Plantation 35 yo \\
Elevation (m.a.s.1.) & 1720 & 1700 & 1300 \\
Annual rainfall (mm) & 2400 & 2400 & 2300 \\
Mean annual temperature $\left({ }^{\circ} \mathrm{C}\right)$ & 17 & 18 & 22 \\
Holdridge life zone & Lower montane wet forest & Lower Montane wet forest & Premontane wet forest \\
Plot size (subplots) & 0.5 ha (50) & 0.5 ha (50) & 0.5 ha (50) \\
Forest connectivity* & High & Medium & Low \\
\hline
\end{tabular}

OF: Old Secondary Forest, YF: Young Secondary Forest, CP: Cypress Plantation. *Forest connectivity refers to the degree of connection to continuous and non-disturbed cloud forest around the plot areas. 
silhouette drawings for every lichen. Similar templates have been utilized in lichen biomonitoring, and has been successfully tested for pollution studies in Costa Rica (Monge-Nájera et al., 2002; Neurohr et al., 2011). The cardinal orientation points were changed systematically for every chosen tree, to confound any microsite differences introduced by trunk face orientation due to light, wind, moisture, slope aspect, and stem flow. Tree sample size varied between plots because some chosen trees ended with no lichens. The final sampled trees with lichens were 20, 30, and 25 for the OF, YF, and CP plots.

In the field, a photograph of every tree bark and template was also taken, and a lichen sample was collected for identification. A total of 75 templates were sampled for a total of 13 $800 \mathrm{~cm}^{2}$. Taxonomic keys to assign lichen's genera (Sipman, 2020) and other published keys were used for species identification (i.e. Sipman et al., 2012). Species not completely identified were considered as morphotypes and treated as species for the analyses. The taxonomic resolution was $100 \%$ at the family and genera level, and $50 \%$ at the species level. Voucher samples were deposited in the herbarium at the Instituto Nacional de Biodiversidad, Heredia, Costa Rica.

Data Analysis: Every template was analyzed with the Image Tools program, (UTHSCSA, Texas, USA) for recording individual lichen surface area. The sampling method allowed to calculate the relative frequency, density, and area-based dominance of lichens. The Importance Value Index (IVI) per species by forest was calculated as the sum of the relative frequency (number of times in different templates/ number of templates of all species), plus the relative abundance (number of individual/total number of individual) plus the relative dominance (surface area of every lichen species/ total surface area of all lichens of all species) of every species, based on a modified method applied for lichens by Pinokiyo et al. (2008). The IVI calculations were also performed grouping species by lichen families, to obtain the Family Importance Value Index (FIVI). A species-rank ordination based on IVI by forest was also performed; the species accumulation curve was calculated with both the number of individuals using the Fisher alpha index to estimate the number of species up to 1000 individuals and with the number of plots per site, using the Clench model (Fagan \& Kareiva, 1997), respectively.

The following diversity and community index were calculated: Shannon-Wiener Index (log base two), evenness (J), Fisher alpha $(\alpha)$, species richness per 100 and 200 individuals from $\alpha$ (S100 y S200, respectively), Simpson reciprocal Index (1/D), average species richness per plot $(\varphi)$, beta diversity $(\beta=\gamma / \varphi)$ which is used here as the number of species change across sites (Neitlich \& McCune, 1997), gamma diversity $(\gamma=$ total species richness), and $\gamma$ '(first-order jackknife estimator of total species richness), as in Palmer (1990). The mean lichen species per plot (template) $(\varphi)$ was analyzed with a Kruskal-Wallis test. We calculated the qualitative species similarity index of Sørensen (Polo, 2008) and the quantitative Bray-Curtis (BC) calculated as 1 minus $B C$ value (Krebs 1999), among the three sites. All diversity analyses were performed with the "Vegan" package" (Oksanen et al., 2014) in the $\mathrm{R}$ language program ( $\mathrm{R}$ Core Team, 2020). Finally, non-metric multidimensional scaling (NMDS) for abundance, frequency, dominance, and presence/absence of the lichen species for three forest covers were done with the "Vegan" package" in R; abundance, frequency, and dominance data were standardized by dividing the values by the total margin and then obtaining the square root (see details in Legendre \& Gallagher, 2001). We also tested the hypothesis that the ecological importance of the species differs between sites from a random distribution by comparing the number of species assigned to three categories of percentile distribution of the IVI values (0-33.3, 33.3-66.6, and 66.6-100). A homogeneity test adjusted by a Fisher correction based on a species categorization was applied. 


\section{RESULTS}

Importance Values and species-area curve: A total of 64 species of lichens were found on the three studied sites, belonging to 25 families. Sixteen percent of the entire sampled area was covered by lichens. The YF showed the highest species richness (42 species), followed by the CP (23 species) and the OF (21 species) (Digital Appendix 1, Digital Appendix 2, Digital Appendix 3). Cryptothecia sp. had the highest IVI in the three sites, increasing in the following order: OF (10.4\%), YF (15.6 $\%)$, and CP (24\%). These lichen communities are characterized by a large proportion of species with a low IVI (Digital Appendix1, Digital Appendix 2, Digital Appendix 3). More than $87 \%$ of the lichen species present in the three sites had an IVI lower than $10 \%$. In the OF site (Digital Appendix 1), $57 \%$ of lichen species have an IVI less than $5 \%$, increasing to the 77 and $90 \%$ in the $\mathrm{CP}$ and YF sites, respectively (Digital Appendix 1). The top three species have an IVI of 29,31 , and $54 \%$ in the OF, YF, and $\mathrm{CP}$ sites, respectively.

The three forests contain a contrasting number of families, with 15, 20 and 10 families in the OF, YF, and CP sites, respectively. The family Arthoniaceae occupied the highest IVI in the CP site, followed by the YF and the smaller IVI in the OF site (Digital Appendix 4, Digital Appendix 5, Digital Appendix 6). In the CP site, the family Arthoniaceae reached 51
$\%$ importance value given the high abundance and dominance of a Cryptothecia species and five different Herpothallon species. However, the IVI for this family went down to 22.8 in the YF and $12 \%$ in the OF (Digital Appendix 4). The top three families in the OF, YF, and CP sites had a FIVI of 36.2, 48.5, and $74.8 \%$, respectively. The other two families in the top three were completely different between sites: Lobariaceae and Hygrophoraceae in the OF, Pyrenulaceae and Parmeliaceae in the YF, and Stereocaulaceae and Coenogoniaceae in the OF, adding about 23,20 , and $13 \%$ of the FIVI in the three sites, respectively.

IVI-based species-rank curves showed striking differences among sites (Fig. 1A). The OF and YF curves show an almost perfect reverted sigmoid curve, but a steady decline in the OF site. The species accumulation curves based on the Fisher $\alpha$ showed similarities between all three sites, they are concave downwards, and showing that the OF had intermediate species richness. None of the curves seems to reach an asymptote (Fig. 1B). However, species accumulation curve based on the sampled plots on the trees (Fig. 1C) suggested that sampling effort was sufficient to get an estimation of species richness of the corticolous lichens in the three communities.

Richness and diversity indexes: The YF site had the highest species richness and diversity as a whole, followed by the OF and the
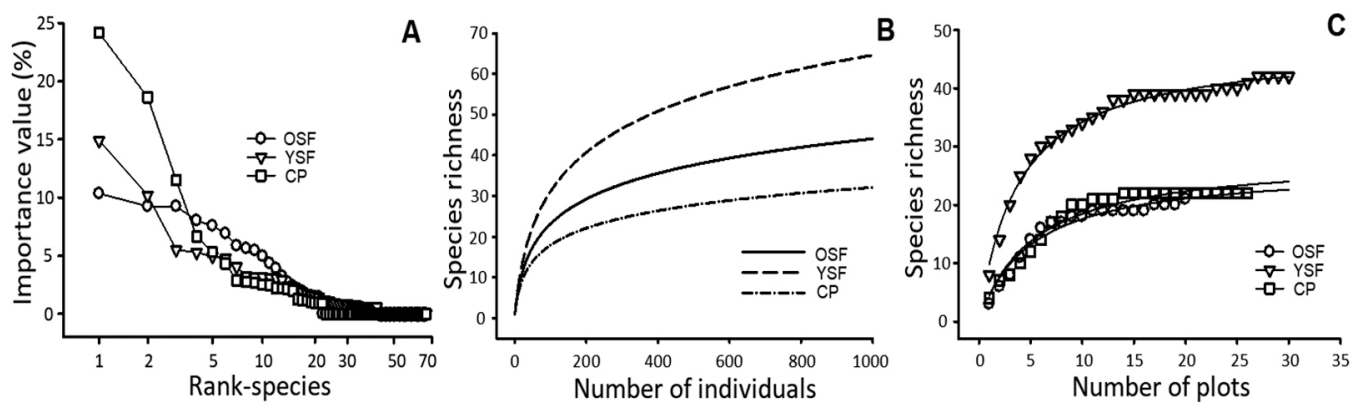

Fig. 1. Species-rank curves based on the A. Importance Value Index (IVI), B. Species accumulation curve per number of individuals through Fisher $\alpha$ index, and C. Species accumulation curve per number of plots for three forests cover in Orosí Valley, Costa Rica. In C, solid lines represent a Clench model for three forests covers. OF: Old Secondary Forest, YF: Young Secondary Forest, CP: Cypress Plantation. 
CP sites (Table 2). Also, the YF had the highest species number according to the $\mathrm{S} 100$ and S200 predictions, the Beta, the gamma, the gamma' jackknife estimator, and the highest $\mathrm{H}_{\max }$. However, the $\mathrm{CP}$ site had the lowest species number, but the Fisher $\alpha, \mathrm{S} 100$, and S200, Simpson reciprocal, but Beta diversity were greater than the values of the OF. In addition, the OF site shows the best evenness as expressed by the $\mathrm{J}^{\prime}$ index (Table 2). However, there was no difference between the mean number of species per tree template between the three sites, with the OF having less than two species per sampled tree.
Community similarity: Both the similarity coefficient and the Bray-Curtis Index showed remarkable low values between compared sites, confirming a particularly low resemblance in lichen communities over the three sites. Both indexes differ at identifying the two most dissimilar sites: YF/CP pair (by Sørensen Coefficient), and the OF/CP pair (by the Bray-Curtis index) (Table 3). In addition, the homogeneity test showed that the number of species based on the IVI values (by sites) do not follow a random distribution (Table 4).

Non-metric multidimensional scaling (NMDS): Community data of lichens for

TABLE 2. Richness and diversity indexes estimated for each forest type

\begin{tabular}{cccc}
\hline & OF & YF & CP \\
\hline $\mathrm{N}$ & 20 & 30 & 25 \\
$\mathrm{H}^{\prime}$ & 4.02 & 4.80 & 3.30 \\
$\mathrm{H}_{\max }$ & 4.39 & 5.46 & 4.52 \\
$\mathrm{~J}^{\prime}$ & 0.92 & 0.88 & 0.73 \\
$\alpha$ & 9.43 & 15.44 & 6.34 \\
$\mathrm{~S}_{100}$ & 23 & 31 & 18 \\
$\mathrm{~S}_{200}$ & 29 & 41 & 22 \\
$1 / \mathrm{D}$ & 14.17 & 21.62 & 5.85 \\
$\boldsymbol{\varphi}( \pm \mathrm{SE}) *$ & $1.70(0.21)$ & $2.78(0.40)$ & $2.16(0.19)$ \\
$\beta$ & 12.35 & 15.11 & 10.19 \\
$\mathrm{~g}^{\prime * *}$ & 21 & 42 & 22 \\
\hline
\end{tabular}

$\mathrm{N}$ : numbers of plots per site, $\mathrm{H}^{\prime}$ : Shannon-Wiener's index, $\mathrm{J}^{\prime}$ : evenness $\left(\mathrm{H}^{\prime} / \mathrm{H}_{\max }\right)$, $\boldsymbol{\alpha}$ : Fisher alpha, $\mathrm{S}_{100}$ y $\mathrm{S}_{200}$ are species richness per each 100 and 200 individuals from $\boldsymbol{\alpha}$, respectively, 1/D: Simpsons's index, $\boldsymbol{\varphi}$ : average species richness per plot ( \pm standard error), $\boldsymbol{\beta}$ : beta $(\gamma / \boldsymbol{\varphi}), \gamma$ : gamma diversity (total species richness), and $\mathrm{g}^{\prime}$ : first-order jackknife estimator of total species richness.

$*$ Kruskall-Wallis's test between sites $=3.274$, d.f. $=2,75, \mathrm{P}>0.05$.

** The estimate for $\mathrm{g}^{\prime}$ is based on the number of single-occurrence species in the plots (Palmer, 1990). OF: Old Secondary Forest, YF: Young Secondary Forest, CP: Cypress Plantation.

TABLE 3. Community similarity based on Sørensen similarity coefficient and the Bray-Curtis Index between forest covers

\begin{tabular}{llccc}
\multirow{3}{*}{ Bray-Curtis } & \multicolumn{3}{c}{ Sørensen similarity coefficient } \\
& & OF & YF & $0.33(7)$ \\
& OF & - & $0.34(11)$ & $0.28(9)$ \\
YF & 0.19 & - & 0.26 & - \\
\hline
\end{tabular}

Upper right: Sorensen similarity coefficient, in brackets the number of species shared, and down left: Bray-Curtis. OF: Old Secondary Forest, YF: Young Secondary Forest, CP: Cypress Plantation. 
TABLE 4. Number of species classified by the importance value index (IVI) percentile categories for the three forests

\begin{tabular}{cccc}
\hline & \multicolumn{3}{c}{ IVI } \\
\hline OF & $\geq 66.7^{\text {th }}$ percentile & $66.7^{\text {th }}-33.3^{\text {th }}$ percentile & $\leq 33.3^{\text {th }}$ percentile \\
\cline { 2 - 4 } YF & 9 & 3 & 9 \\
CP & 4 & 8 & 30 \\
\end{tabular}

Fisher adjusted $\chi^{2}, \mathrm{P}=0.019$. OF: Old Secondary Forest, YF: Young Secondary Forest, CP: Cypress Plantation.

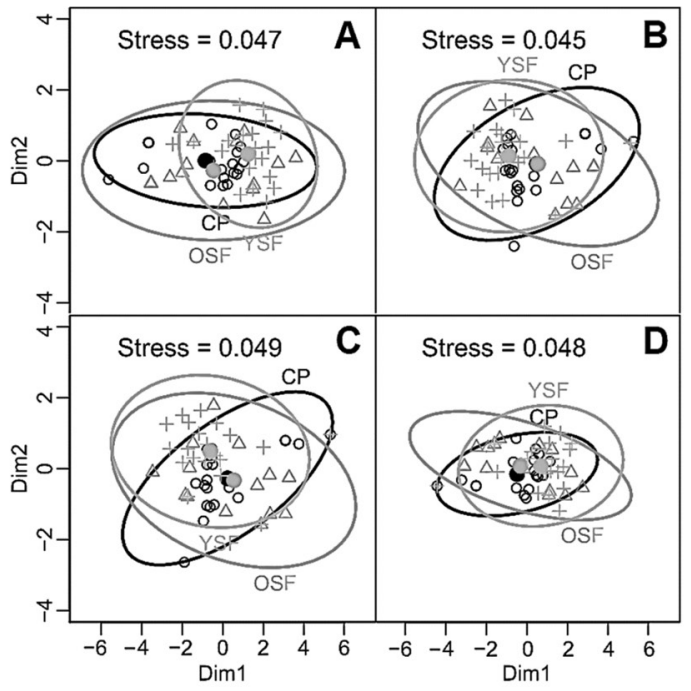

Fig. 2. Non-metric Multi-dimensional Scaling $(N M D S)$ for A. Abundance, B. Frequency, C. Dominance, and D. Presence/ absence of lichens for community data for the three forests in the Orosí Valley, Costa Rica. OF: Old Secondary Forest, YF: Young Secondary Forest, CP: Cypress Plantation.

subplot sample did not show a clustering for abundance, frequency, dominance, and presence/absence for three forest covers (Fig. 2A, Fig. 2B, Fig. 2C and Fig. 2D, respectively; NMDS with stress index less than 0.049).

\section{DISCUSSION}

The species diversity and community composition of the corticolous lichens in the mountains of the Orosí Valley seem to be relatively high considering the sampling effort, the taxonomic resolution, the restricted tree stem sampling, and the ecological life zones studied. Compared to lower-elevation tropical forests, diversity is much lower than the 217 foliaceous lichen species sampled in the lowland rain forest of Costa Rica (Lücking, 1999a), or the 150 corticolous crustose lichen species in the Brazilian Atlantic rain forest (Cáceres et al., 2007), but very similar to the 61 species found in degraded dry forest remnants in Colombia (Lücking et al., 2019). The most important component of the corticolous lichen diversity appears to belong to lichens occurring in relatively open and early successional fields.

Lichen traits, richness and diversity: Temperate and boreal data suggest that there is a corresponding relationship between forest complexity and lichen biomass, and its diversity (Crites \& Dale, 1998). However, the present analyses indicate that young successional forest (13 yo) contains a greater number of 
lichens and significantly high species richness and diversity. Traditionally, lichens have been categorized as open area dwellers, a trait biased by the ability of lichens to cope with extreme habitats around the world, where they seem to reach higher biodiversity values (Galloway, 1992). In this sense, the present study entirely agrees with this general trend. This typical situation is favored because the YF contains a high concentration of small-diameter trees along with the abandoned and relatively older trees of S. jambos (Myrtaceae), which were practically covered by mosses and lichens, creating ideal microclimatic conditions based on a minutely grained gradient of moisture and light. Contrarily, the foliaceous lichen community from tropical lowland forest (Lücking, 1999b) presented a reduced species account for open, human-modified vegetation by lacking typical forest understory species.

Lichen species composition also varies greatly along gradients of temperature and moisture (Neitlich \& McCune, 1997; Crites \& Dale, 1998). Given the climatic and topographic traits of this region, along with abandoned farms, early and intermediate successional areas, all may play a significant role in the maintenance and dynamics for lichen species richness, providing habitats and a great availability of tree trunk phorophytes that interact with the microenvironmental gradients. As previously stated, the boundary layer scale of micro topographic microsites may generate a significant gradient of smaller-scale strategies for poikilohydric organisms (Proctor, 2014). However, tree trunk microenvironments below canopies of natural forests, like in the old secondary forest, can be considered highly homogeneous, providing a dim environment, and much more constant humidity conditions, which could be restricting the growth and development of many lichen species.

A large amount of information demonstrated that tree species, bark texture, bark $\mathrm{pH}$, lenticels traits, milk sap (Cáceres et al., 2007), circumference and inclination of the trunk were relevant factors influencing the abundance and distribution of lichen species worldwide, explaining about $50 \%$ of the total variation (Cristofolini et al., 2008). In this sense, we found the lower evenness, and lower Fisher $\alpha$ and $\beta$ diversities in the CP site (Table 2 ), where all sampled trees were $C$. lusitanica. This situation indicates obvious differences in the availability and bark trait parameters of potential phorophytes between the three tree communities studied.

Lichen community patterns: These lichen communities follow the typical pattern of tropical tree communities; a dominance of very common and few species in combination with a great number of very uncommon or "rare" species (Condit et al., 1996). Mean species per tree trunk was lowest in the $\mathrm{OF}$ trees, which suggests dimmer light conditions within the forest and greater competition for corticolous habitats with bark bryophytes. The more complex OF site showed the higher evenness, and it was situated in intermediate positions in the ranking of indexes calculated. This situation is also reflected in the importance values calculated at family level, where the second and third most important families were completely different in the three sites. Even though species composition in a given area has a strong effect on the biogeographical affinities between species (Santos et al., 2020) and higher taxa, it is possible to hypothesize that specific microclimatic conditions may select for distantly related species adapted to them. In other words, species composition may rely on a gradient of fine-tune microenvironmental preferences from a pool of ecologically equal species randomly established. This suggestion has also been addressed from diversity and species/ area curves from tree species communities in complex structures in large-scale areas (Condit et al., 1996; Condit et al., 2005). Second, it is well known that lichen richness is high at edge environments such as the forest-grassland ecotone, and this trend hold for both hemispheres (Galloway, 1992) which supports the idea of the YF possessing the highest diversity. And, third, local or regional level lichen biodiversity 
may be the result of disturbance (Galloway, 1992), which produces a much richer and heterogeneous habitat for lichens than the one in the understory of an almost fully developed forest. In this sense, a dynamic perturbation cycle for a long period of human intervened landscape along with sequential changes of available land abandonment may provide the required potential for the maintenance of a highly dynamic species turnover, mainly based on the high species source provided by the relatively close, pristine and gigantic forest conservation area. Finally, it is possible that our final community composition is also affected by the stochastic effects of species dispersal, especially of rare species, as suggested by Cáceres et al. (2007) for the formation of a lichen community in a tropical rainforest understory. Dispersal limitation has also been suggested to affect similarly the successful establishment of epiphytic bromeliads in the interiors of tropical montane forests (Cascante-Marín et al., 2009).

As a result, we detect a strong resemblance of community structure of the three sites but great differences in ecological importance and composition. The species richness gradient between the three restoration sites seems to be enhanced by the way the species assemblages were developed in time, microclimatic conditions in and around the phorophytes, and in other factors determining lichen abundance and establishment, such as light environment, phorophyte specificity, temperature and moisture gradients, and site history. These characteristics are determinants of the heterogeneity of the species composition and in turn are associated with the high abundance of rare species on a larger scale (Enquist et al., 2019). Such rarity seems to define the strong dissimilarity of the studied forest stands, e.g., phorophyte specificity was explained for the NMDS analysis, because colonization aspects of lichen are heterogeneous at the level of the host tree in a forest stand with high tree diversity, leading to the non-clustering and differentiation of the lichen community.
Lichens as indicator species: This study suggests the use of the importance of the lichen genera Cryptothecia as indicator of ecological position of forested areas in the mountains surrounding the Oriental Central Valley of Costa Rica. This species is dominant in the OF but with a relatively low IVI value. Its ecological importance increased in the YF and even more in the $\mathrm{CP}$, reflecting a negative relationship with forest integrity reflecting some passive restoration traits such as restoration age, vegetation structure, and microclimate variations, and some possible substrate-specific traits for lichen formation associated to the diversity of phorophytes. As a whole, there was not any relationship between restoration preference, forest condition, and association of lichen families as found for a variety of dry and lowland environments of Costa Rica as found by RivasPlata et al. (2008), possibly as a consequence of the extreme differences in sampling between studies, or because our study is located in the highest part of the elevation gradient considered in that study. This is why developing a fast indicator procedure for forest condition and fragmentation status must be established cautiously and clearly restricted and applied to the life zone considered and the level of human interventions. As hemeroby bioindicators, we support Williams and Ellis (2018) conclusion about the importance of the spatial associations between forest fragments to interpret individual lichen species or family indicators as markers of threat and conservation value.

Restoration implications: The entire region has probably the potential for greater species richness; however, dispersal limitation associated with a strong habitat fragmentation after a long history of human utilization of resources produced the present and reduced local species diversity. Natural and passive restoration efforts are slow but better strategies for obtaining a more structured and diverse lichen community. As previously stated by McCune (2000) for some temperate ecosystems, this study will contribute and will provide the 
documentation of invasion and extinction of species, the lichen species distributions along with larger scales, and it will enhance the appreciation for lichens given its importance for ecosystem functioning and diversity.

From a practical point of view, practitioners may use this simple methodology by monitoring lichen diversity for easy comparisons of forest integrity and restoration trajectories. However, an analysis of the ecological complexity of tropical forests from lichen communities has to be considered carefully by defining a complete sampling of the different microenvironments they live, and the ecological and phorophyte preferences, and life forms. Practitioners may also apply this method for a description of vertical gradients in lichen community composition as a way to relate them to corresponding changes in canopy structure. They need to be careful because they may also indicate differences in successional gradients, through vertical displacement as the forest became older (Neitlich \& McCune, 1997; WillWolf et al., 2006).

Ethical statement: authors declare that they all agree with this publication and made significant contributions; that there is no conflict of interest of any kind; and that we followed all pertinent ethical and legal procedures and requirements. All financial sources are fully and clearly stated in the acknowledgements section. A signed document has been filed in the journal archives.

\section{ACKNOWLEDGMENTS}

We greatly appreciate the suggestions to previous versions of this manuscript to $R$. Lücking, and to Deanna Sekulich, Kotochi B. Anita, and Stefany Solano for revising the English. We give our thanks to ICE and Estación de Acuicultura and Biología Tropical de Río Macho for facilities provided. To SINAC for facilitation of research permits. This study was funded by a Fondo Especial de Educación Superior (FEES) from the Consejo Nacional de Rectores (CONARE) of Costa Rica to RCS.

\section{RESUMEN}

Estructura y riqueza de la comunidad liquénica de tres bosques secundarios de elevación media en Costa Rica

Introducción: La diversidad de líquenes, la estructura y composición de la comunidad y la abundancia de algunas especies y familias se ha usado como indicadores de la salud y continuidad ecológica de los ecosistemas boscosos tropicales. Objetivos: Evaluar la composición, diversidad e importancia ecológica de las especies de líquenes en tres ecosistemas boscosos que difieren en el tiempo regeneración natural, como indicadores de la influencia de la restauración pasiva en el ensamble de la comunidad de líquenes cortícolas. Métodos: Se midieron los líquenes individuales sobre los troncos de árboles en un bosque secundario avanzado (OF), en un bosque secundario joven (YF, con 50 y 14 años de regeneración natural tras abandono del potrero, respectivamente), y en una plantación abandonada de ciprés exótico con 35 años de edad (CP), en la región oriental del Valle Central de Costa Rica. Se calcularon los índices estándares de diversidad, similitud y valor de importancia (IVI), además de un análisis de NMDS sobre los parámetros de la estructura de la comunidad en una matriz de presencia-ausencia. Resultados: Encontramos 64 especies en 25 familias, con 42, 23 y 21 especies y 20, 10 y 15 familias en los sitios YF, CP y OF, respectivamente. Una especie de Cryptothecia sp. presentó el IVI más alto en los tres bosques. Más del $87 \%$ de las especies son raras. El IVI combinado de las tres familias más importantes fue: 36 , 48.5 y $74.8 \%$ en los sitios: YF, OF y CP, respectivamente. Arthoniaceae está entre las tres familias más importantes en los tres sitios. El YF es el sitio con más especies, pero el sitio OF presentó la mayor igualdad. Los índices de similitud y diversidad sugieren una semejanza particularmente baja entre las comunidades liquénicas, pero separadas por una gradiente de diferenciación difusa entre los tres sitios, lo cual es confirmado por el análisis NMDS. La prueba de homogeneidad confirmó grandes diferencias en la importancia ecológica y la composición. Conclusiones: La región contiene un ensamblaje propio de especies que resulta en una fuerte diferenciación comunitaria entre bosques, reflejo de la influencia de factores ecofisiológicos y microclimáticos en el establecimiento y supervivencia de líquenes; lo que sugiere una gran diversidad beta regional, en un paisaje fragmentado. Una mayor conectividad y estrategias de restauración pasiva dieron como resultado una mayor diversidad y una estructura comunitaria más heterogénea en ambos bosques que la comunidad cortícola de la plantación exótica abandonada. La protección de fragmentos forestales maximizará la integridad de los bosques futuros.

Key words: bosque nuboso; composición de la comunidad; Costa Rica; líquenes cortícolas; hemerobia; diversidad de líquenes. 


\section{REFERENCES}

Berryman, S., \& McCune, B. (2006). Estimating epiphytic macrolichen biomass from topography, stand structure and lichen community data. Journal of Vegetation Science, 17(2), 157-170. https://doi. org/10.1111/j.1654-1103.2006.tb02435.x

Bustamante, E.N., Monge-Nájera, J., \& González Lutz, M.I. (2011). Air pollution in a tropical city: the relationship between wind direction and lichen bioindicators in San José, Costa Rica. Revista de Biología Tropical, 59(2), 899-905. http://www.ncbi.nlm. nih.gov/pubmed/21717859

Cáceres, M.E.S., Lücking, R., \& Rambold, G. (2007). Phorophyte specificity and environmental parameters versus stochasticity as determinants for species composition of corticolous crustose lichen communities in the Atlantic rain forest of Northeastern Brazil. Mycological Progress, 6(3), 117-136. https://doi. org/10.1007/s11557-007-0532-2

Cascante-Marín, A., Von Meijenfeldt, N., De Leeuw, H.M.H., Wolf, J.H.D., Gerard, J., Oostermeijer, B., \& Den Nijs, J.C.M. (2009). Dispersal limitation in epiphytic bromeliad communities in a Costa Rican fragmented montane landscape. Journal of Tropical Ecology, 25(1), 63-73. https://doi.org/10.1017/ S0266467408005622

Condit, R., Ashton, P., Balslev, H., Brokaw, N., Bunyavejchewin, S., Chuyong, G., \& Zimmerman, J.K. (2005). Tropical tree a-diversity: Results from a worldwide network of large plots. Biologiske Skrifter $55,565-582$.

Condit, R., Hubbell, S.P., Lafrankie, J.V., Sukumar, R., Manokaran, N., Foster, R.B., \& Ashton, P.S. (1996). Species-area and species-individual of three 50-ha plots trees: a comparison of three 50-ha plots. Journal of Ecology, 84(4), 549-562.

Cornelissen, J.H.C., Callaghan, T.V., Alatalo, J.M., Michelsen, A., Graglia, E., Hartley, A.E., Hik, D.S., Hobbie, S.E., Press, M.C., Robinson, C.H., Henry, G.H.R., Shaver, G.R., Phoenix, G.K., Gwynn Jones, D., Jonasson, S., Chapin III, F.S., Molau, U., Neill, C., Lee, J.A., ... Aerts, R. (2001). Global change and arctic ecosystems: Is lichen decline a function of increases in vascular plant biomass? Journal of Ecology, 89(6), 984-994. https://doi. org/10.1046/j.1365-2745.2001.00625.x

Cristofolini, F., Giordani, P., Gottardini, E., \& Modenesi, P. (2008). The response of epiphytic lichens to air pollution and subsets of ecological predictors: a case study from the Italian Prealps. Environmental Pollution, 151(2), 308-317. https://doi.org/10.1016/j. envpol.2007.06.040

Crites, S., \& Dale, M.R.T. (1998). Diversity and abundance of bryophytes, lichens, and fungi in relation to woody substrate and successional stage in aspen mixedwood boreal forests. Canadian Journal of Botany, 76(4), 641-651. https://doi.org/10.1139/b98-030

Enquist, B.J., Feng, X., Boyle, B., Maitner, B., Newman, E.A., Jørgensen, P.M., Roehrdanz, P.R., Thiers, B.M., Burger, J.R., Corlett, R.T., Couvreur, T.L.P., Dauby, G., Donoghue, J.C., Foden, W., Lovett, J.C., Marquet, P.A., Merow, C., Midgley, G., Morueta-Holme, N., ... McGill, B.J. (2019). The commonness of rarity: Global and future distribution of rarity across land plants. Science Advances, 5(11), eaaz0414. https:// doi.org/10.1126/sciadv.aaz0414

Estrabou, C., Stiefkens, L., Hadid, M., Rodríguez, J.M., \& Pérez, A. (2005). Estudio Comparativo de la Comunidad Liquénica en Cuatro Ecosistemas de la Provincia de Córdoba. Boletín de la Sociedad Argentina de Botanica, 40(1-2), 1-10.

Fagan, W.F., \& Kareiva, P.M. (1997). Using compiled species lists to make biodiversity comparisons among regions: A test case using Oregon butterflies. Biological Conservation, 80(3), 249-259. https://doi. org/10.1016/S0006-3207(96)00144-9

Galloway, D.J. (1992). Biodiversity: a lichenological perspective. Biodiversity and Conservation, 1(4), 312-323.

Gasparyan, A., Sipman, H.J.M., Marini, L., \& Nascimbene, J. (2018). The inclusion of overlooked lichen microhabitats in standardized forest biodiversity monitoring. Lichenologist, 50(2), 231-237. https://doi. org/10.1017/S0024282918000087

Giordani, P. (2007). Is the diversity of epiphytic lichens a reliable indicator of air pollution? A case study from Italy. Environmental Pollution, 146(2), 317-323. https://doi.org/10.1016/j.envpol.2006.03.030

Heltshe, J.F., \& Forrester, N.E. (1983). Estimating species richness using the jackknife procedure. Biometrics, $39,1-11$.

Honegger, R. (1991). Functional aspects of the lichen symbiosis. Annual Review of Plant Biology, 42, 553-578.

Hubbell, S.P. (2001). The unified neutral theory of biodiversity and biogeography. Princeton University Press.

Krebs, C.J. (1999). Ecological methodology. Addison.

Legendre, P., \& Gallagher, E.D. (2001). Ecologically meaningful transformations for ordination of species data. Oecologia, 129(2), 271-280.

Lehmkuhl, J.F. (2004). Epiphytic lichen diversity and biomass in low-elevation forests of the eastern Washington Cascade Range, USA. Forest Ecology and Management, 187(2-3), 381-392. https://doi. org/10.1016/j.foreco.2003.07.003

López, W., \& Duque, Á. (2010). Patrones de diversidad alfa en tres fragmentos de bosques montanos en la 
región norte de los Andes, Colombia. Revista de Biología Tropical, 58(1), 483-498.

Lücking, R. (1999a). Ecology of Folicolous Lichens at the "Botarrama" Trail (Costa Rica), a Neotropical Rain Forest . I. Species Composition and its Ecogeographical Implications 1. Biotropica, 31(4), 553-564.

Lücking, R. (1999b). Líquenes folícolas de la Estación Biológica La Selva, Costa Rica: Inventario, comunidades y comparación florística de tipos de vegetación. Revista Biología Tropical, 47(3), 287-308.

Lücking, R., Moncada, B., Martínez-Habibe, M.C., Salgado-Negret, B.E., Celis, M., Rojas-Zamora, O., Rodrígez-M, G.M., Brokamp, G., \& Borsch, T. (2019). Lichen diversity in Colombian Caribbean dry forest remnants. Caldasia, 41(1), 194-214.

McCune, B. (2000). New Frontiers in Bryology and Lichenology Lichen Communities as Indicators of Forest Health. The Bryologist, 103(2), 353-356.

Monge-Nájera, J., González, M.I., Rivas, M., \& MéndezEstrada, V.H. (2002). A new method to assess air pollution using lichens as bioindicators. Revista Biología Tropical, 50(1), 321-325. http://www.ncbi.nlm. nih.gov/pubmed/12298260

Neitlich, P., \& McCune, B. (1997). Hotspots of lichen diversity in Two young managed forests. Conservation Biology, 11(1), 172-182.

Neurohr, E., Monge-Nájera, J., \& González-Lutz, M. (2011). Air pollution in a tropical city: the relationship between wind direction and lichen bio-indicators in San José, Costa Rica. Revista Biología Tropical, 59(2), 889-905.

Oksanen, J., Blanchet, F.G., Kindt, R., Legendre, P., Minchin, P.R., O’Hara, R.B., Simpson, G.L., Solymos, P., Henry, M., Stevens, H., \& Wagner, H. (2014). Vegan Community Ecology Package. (Version 2.2-0., R Package). https://www.scirp.org/ (S(351jmbntvnsjt1aadkposzje))/reference/ReferencesPapers.aspx?ReferenceID=1778707

Ortiz-Malavassi, E. (2014). Atlas digital de Costa Rica 2014. Tecnológico de Costa Rica. https://hdl.handle. net/2238/6749

Palmer, M.W. (1990). The Estimation of Species Richness by Extrapolation. Ecology, 71(3), 1195-1198. https:// doi.org/10.2307/1937387

Petrokas, R., \& Baliuckas, V. (2017). Self-sustaining forest. Applied Ecology and Environmental Research, 15(4), 409-426.

Pinokiyo, A., Singh, K.P., \& Singh, J.S. (2008). Diversity and distribution of lichens in relation to altitude within a protected biodiversity hot spot, north-east India. Lichenologist, 40(1), 47-62.
Polo, C. (2008). Índices más comunes en biología. Segunda parte, similaridad y riqueza beta y gamma. Revista Facultad de Ciencias Básicas, 4(1-2), 135-142.

Proctor, M.C. (2014). The diversification of bryophytes and vascular plants in evolving terrestrial environments. In D.T. Janson \& S.K. Rice (Eds.), Photosynthesis in bryophytes and early land plants (pp. 59-77). Springer.

R Core Team (2020). R: A language and environment for statistical computing. $R$ Foundation for Statistical Computing. Vienna, Austria. https://www.R-project. org/

Rivas-Plata, E., Lücking, R., \& Lumbsch, H.T. (2008). When family matters: An analysis of Thelotremataceae (Lichenized Ascomycota: Ostropales) as bioindicators of ecological continuity in tropical forests. Biodiversity and Conservation, 17(6), 1319-1351. https://doi.org/10.1007/s10531-007-9289-9

Santos, V.M., Cáceres, M.E.S., \& Lücking, R. (2020). Diversity of foliicolous lichens in isolated montane rainforests (Brejos) of northeastern Brazil and their biogeography in a neotropical context. Ecological Research, 35(1), 182-197. https://doi. org/10.1111/1440-1703.12071

Sipman, H.J. (2020). Identification key and literature guide to the genera of Lichenized Fungi (Lichens) in the Neotropics. Botanic Garden \& Botanical Museum Berlin-Dahlem. https://archive.bgbm.org/BGBM/ STAFF/Wiss/Sipman/keys/neokeyA.htm

Sipman, H.J., Lücking, R., Aptroot, A., Chaves, J.L., Kalb, K., \& Tenorio, L.U. (2012). A first assessment of the Ticolichen biodiversity inventory in Costa Rica and adjacent areas: the thelotremoid Graphidaceae (Ascomycota: Ostropales). Phytotaxa, 55(1), 1-214. https://doi.org/10.11646/phytotaxa.55.1.1

Spake, R., Ezard, T.H.G., Martin, P.A., Newton, A.C., \& Doncaster, C.P. (2015). A meta-analysis of functional group responses to forest recovery outside of the tropics. Conservation Biology, 29(6), 1695-1703. https://doi.org/10.1111/cobi.12548

Thüs, H., Wolseley, P., Carpenter, D., Eggleton, P., Reynolds, G., Vairappan, C.S., Weerakoon, G., \& Mrowicki, R.J. (2021). Key Roles of Dipterocarpaceae, Bark Type Diversity and Tree Size in Lowland Rainforests of Northeast Borneo-Using Functional Traits of Lichens to Distinguish Plots of Old Growth and Regenerating Logged Forests. Microorganisms, 9(3), 541. https://doi.org/10.3390/microorganisms 9030541

Will-Wolf, S., Geiser, L.H., Neitlich, P., \& Reis, A.H. (2006). Forest lichen communities and environment-How consistent are relationships across scales? Journal of Vegetation Science, 17(2), 171. https://doi. org/10.1658/1100-9233(2006)17[171:flcaec]2.0.co;2

Williams, L., \& Ellis, C.J. (2018). Ecological constraints to 'old-growth'lichen indicators: niche specialism or dispersal limitation? Fungal Ecology, 34, 20-27. 